\title{
Development of Loop-Mediated Isothermal Amplification (LAMP) assay for rapid detection of Fusarium oxysporum f. sp. ciceris - wilt pathogen of chickpea
}

Raju Ghosh, Avuthu Nagavardhini, Anindita Sengupta and Mamta Sharma*

\begin{abstract}
Background: Fusarium oxysporum f. sp. ciceris (Foc), the causal agent of Fusarium wilt is a devastating pathogen of chickpea. In chickpea, various soil borne pathogens produce (s) similar symptoms, therefore cannot be distinguished easily at field level. There is real need for a rapid, inexpensive, and easy to operate and maintain genotyping tool to facilitate accurate disease diagnosis and surveillance for better management of Fusarium wilt outbreaks.

Results: In this study, we developed a loop-mediated isothermal amplification (LAMP) assay targeting the elongation factor 1 alpha gene sequence for visual detection of Foc. The LAMP reaction was optimal at $63^{\circ} \mathrm{C}$ for $60 \mathrm{~min}$. When hydroxynaphthol blue (HNB) was added before amplification, samples with Foc DNA developed a characteristic sky blue colour but those without DNA or with the DNA of six other plant pathogenic fungi did not. Results obtained with LAMP and HNB were confirmed when LAMP products were subjected to gel electrophoresis. The detection limit of this LAMP assay for Foc was $10 \mathrm{fg}$ of genomic DNA per reaction, while that of conventional PCR was $100 \mathrm{pg}$.

Conclusions: In conclusion, it was found that a LAMP assay combined with HNB is simple, rapid, sensitive, and specific. The LAMP assay does not require specialized equipment, hence can be used in the field for the rapid detection of Foc. This is the first report of the use of LAMP assay for the detection of Foc. The presented LAMP method provides a specific, sensitive and rapid diagnostic tool for the distinction of Foc, with the potential to be standardized as a detection method for Foc in endemic areas and will be very useful for monitoring the disease complex in the field further suggesting the management strategies.
\end{abstract}

Keywords: Detection, Fusarium oxysporum, Hydroxynaphthol blue, Isothermal amplification, LAMP

\section{Background}

Chickpea (Cicer arietinum L.) is the second largest cultivated legume crop after dry beans globally [1]. It is grown in 54 countries as a rainfed, post-rainy season and winter crop in subtropical South Asia, parts of Africa and Australia and as a spring season crop in the temperate and Mediterranean regions [1]. India is the largest producer of chickpea and accounts for $68.47 \%$ of the total area and $67.02 \%$ of total production globally. Chickpea represents $35.16 \%$ of total pulse area and $50.34 \%$ of total pulse production in India [2].

\footnotetext{
*Correspondence: mamta.sharma@cgiar.org

International Crops Research Institute for the Semi-Arid Tropics (ICRISAT), Patancheru, PO 502324, Andhra Pradesh, India
}

Various biotic and abiotic stresses affect stable and high yields of chickpea crop worldwide. Among the biotic stresses, Fusarium wilt (FW), caused by the asexual, soil borne and seed borne fungus Fusarium oxysporum Schlecht and Emnd Snyd. \& Hans. f. sp. ciceris (Padwick) Snyd. and Hans. (Foc), results in major economic losses ranging from $10-40 \%$ worldwide. It is estimated to cause $10-15 \%$ yield loss annually in India [3], but can result in $100 \%$ losses under favourable conditions. The cultivation of resistant varieties is one of the most durable and economical practices for the management of FW. However, performance of varieties differs from place to place owing to existence of physiological races among the Foc isolates. Eight races of Foc (0, 1A, 1B/C, 2, 3, 4, 5 and 6) 
have been reported worldwide [4-6]. Races 1A (also known as race 1), 2, 3 and 4 have been reported from India, whereas races $0,1 \mathrm{~B} / \mathrm{C}, 5$ and 6 were found mainly in the Mediterranean region and in the United States (California). Recently, change in the distribution of Foc has been reported by Sharma et al. in India [7]. Therefore, to prevent the introduction and spread of Foc races in different new regions of India, a suitable, reliable and rapid detection method is prerequisite. In recent years, PCR-based methods, for instance multiplex and realtime PCR have been developed to detect fungal species and other microorganisms [8-11], however, methods based on PCR can be time-consuming and require the extraction of high-quality DNA due to the effects of inhibitors on PCR sensitivity [12,13]. Loop-mediated isothermal amplification (LAMP) is an alternative amplification technology $[14]$, is highly sensitive, less time-consuming than conventional PCR-based methods, and less prone to inhibition from DNA preparations [15-18]. Amplification by LAMP involves the use of six primers (two internal, two external and two loop primers) and relies on auto cycling DNA synthesis by a DNA polymerase with high strand displacement activity. Both the forward and backward inner primers contain two distinct sequences each, corresponding to the sense and the antisense sequences of the target DNA. Amplification products are characterized by the fact that they contain loop regions to which further primers can bind, allowing the amplification to continue isothermally [14]. The speed of the reaction is accelerated using additional loop primers that bind to those loops which are of the inverse orientation to the loops to which the internal primers bind [19]. Like PCR, LAMP reaction can be monitored in real time using intercalating fluorescent dyes such as ethidium bromide, SYBR Green I, propidium iodide, or Quant-iT PicoGreen; by adding metal-ion indicators such as hydroxynaphthol blue (HNB) [20], $\mathrm{CuSO}_{4}$ [21], or calcein [17] or by measuring the increase in turbidity derived from magnesium pyrophosphate formation (to infer increases in amplified DNA concentration). LAMP products can also be detected by real-time detection methods [22].

The simplicity of the LAMP method, which does not require a thermal cycler, makes it suitable for field testing also. Recently, LAMP assay has been developed for the detection of bacteria [23], viruse [24], and fungi [25]. In chickpea, various pathogens exist simultaneously and difficult to distinguish visibly by looking at symptoms. Fusarium wilt is easily mistaken from Dry root rot, as the general symptoms of these diseases are similar. Affected plants show foliar chlorosis and causes mortality of the plants usually in patches in field. This presents a real need for a rapid, inexpensive and easy to handle tool to facilitate accurate disease diagnosis and surveillance for better management of Fusarium wilt.
The LAMP method has been applied first time for the detection of Foc.

The purpose of the present study was to develop LAMP assay for the detection of Foc and to evaluate the diagnostic sensitivity and specificity of this assay using a panel of fungal DNA samples and infected field samples of chickpea. The newly developed LAMP assay successfully detected Foc with rapidity, specificity, and high sensitivity.

\section{Results}

\section{Design of LAMP primers and assay}

For primer designing, various Foc isolates were examined to identify the conserved regions of the fungus genome and EF-1 alpha gene was chosen. A set of primers were designed by LAMP designer software based upon the conserved regions among isolates and used subsequently for the specificity of the LAMP assay. All the primers were tested by in-silico using the nucleotide BLAST search tool on the NCBI sequence database that revealed significant hits for the target sequences. When the LAMP assay was performed with Foc DNA as the template, the best results were obtained in a $25 \mu \mathrm{L}$ volume containing 2.0- $\mu \mathrm{l}$ primer mixture $(20 \mu \mathrm{M}$ each of FIP, BIP, Loop F, and Loop B primers, and $2.5 \mu \mathrm{M}$ each of F3 and B3 primers) $1.28 \mathrm{M}$ betaine, $1 \mathrm{mM}$ dNTPs, $4 \mathrm{mM} \mathrm{MgCl}_{2}, 20 \mathrm{mM}$ Tris- $\mathrm{HCl}(\mathrm{pH} \mathrm{8.8)}, 10 \mathrm{mM} \mathrm{KCl}$, $10 \mathrm{mM}\left(\mathrm{NH}_{4}\right)_{2} \mathrm{SO}_{4}, 2 \mathrm{mM} \mathrm{MgSO}$, $0.1 \%$ Triton $\mathrm{X}-100,8$ $\mathrm{U}$ of Bst DNA polymerase, $150 \mu \mathrm{M} \mathrm{HNB}$, and $1 \mu \mathrm{L}$ of target DNA. As noted in the methods, the reactions were performed in a $0.2-\mathrm{mL}$ microcentrifuge in a water bath for temperature control. When the tubes were examined before gel electrophoresis, a positive LAMP reaction was indicated by a sky blue colour; the colour remained violet for negative reactions (Figure 1A). After the tubes were visually assessed for colour change, the samples were subjected to agarose gel electrophoresis; characteristic bands were evident in the gel if the product was present but not if the product was absent (Figure 1B). The results showed that the primers were effective, and that the same result was obtained with HNB visualization and gel electrophoresis.

\section{Optimization of LAMP reaction conditions}

With Foc DNA as the template and the reagents optimized as indicated in the previous section, the optimal LAMP reaction time and temperature were determined. When LAMP was conducted at $63^{\circ} \mathrm{C}$, positive results were obtained with times of 30 to $90 \mathrm{~min}$ whether assessment was based on gel electrophoresis (Figure 2A) or by HNB-visualization (Figure 2B) but the ladder-like pattern produced by gel electrophoresis was strongest at $60 \mathrm{~min}$. When LAMP was conducted for $60 \mathrm{~min}$ with a range of test temperatures, all temperatures produced a 


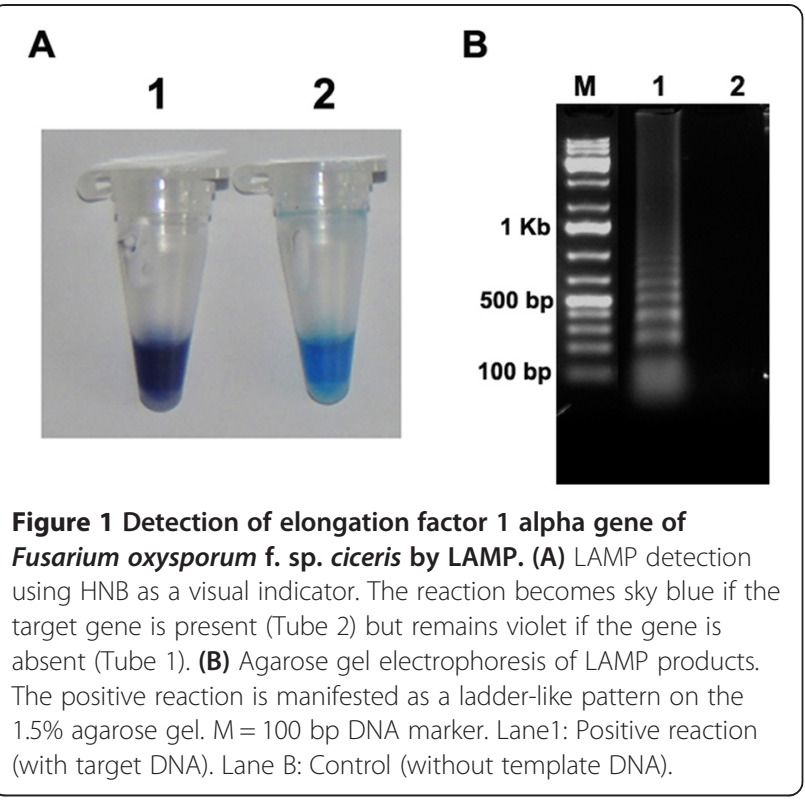

positive reaction whether assessment was based on gel electrophoresis (Figure 2C) or by HNB-visualization (Figure 2D) but the bands obtained with gel electrophoresis were most intense at $63^{\circ} \mathrm{C}$ (Figure 2C). In summary, LAMP of the EF-1alpha gene was optimal when conducted at $63^{\circ} \mathrm{C}$ for $60 \mathrm{~min}$.

\section{Evaluation of LAMP assay}

All the 50 Foc isolates collected from diverse geographical locations in India and representing various races were tested by LAMP and showed the positive reaction as indicated by a sky-blue colour. The results were consistent with PCR method.

\section{Specificity of the LAMP assay}

For the LAMP specificity assay, the assay was performed with template fungal DNA from six other fungal cultures (Fusarium acuminatum, Fusarium udum, Fusarium solani, Rhizoctonia bataticola, Alternaria alternata and Phytophthora cajani) as well as DNA isolated from infected field samples of chickpea (Black root rot caused by Fusarium solani, Dry root rot caused by Rhizoctonia bataticola and Alternaria blight caused by Alternaria alternata). At optimum condition, no positive amplification was observed in case of other fungal DNA samples. Same result was obtained when products were assessed by gel electrophoresis or by HNB-visualization. After incubation at $63^{\circ} \mathrm{C}$ for $60 \mathrm{~min}$, the LAMP assay was positive only for Foc, i.e., no positive DNA products were observed when other plant pathogenic fungi (Figure 3A,B) were used as template. This was true whether assessments were based on gel electrophoresis (Figure 3A) or HNB visualisation (Figure 3B). Similarly, in case of infected plant samples, DNA isolated from Fusarium wilt infected chickpea plants showed positive reaction (Additional file 1: Figure S1). These results indicated that the LAMP technique developed in this study is highly specific for Foc and has distinguished between Foc and six above mentioned common plant pathogenic fungi.

\section{A}
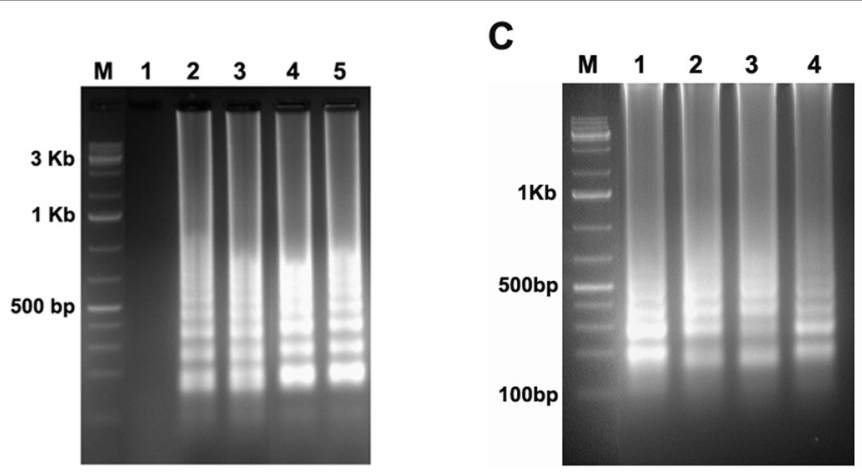

B

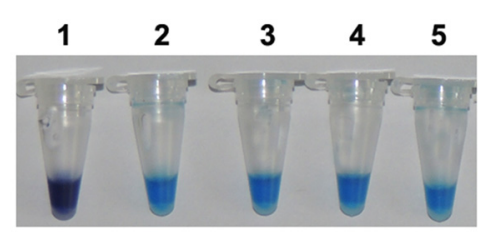

D

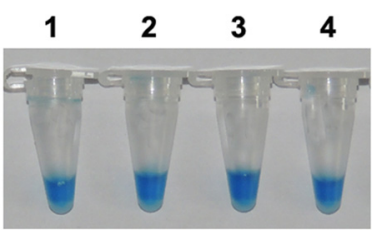

Figure 2 Optimization of LAMP reaction time and reaction temperature. (A,B) Optimization of time, (A) Assessment was based on 1.5\% agarose gel electrophoresis and (B) HNB visualization of colour change. Lane 1: 15 min; lane 2: 30 min; lane 3: 45 min; lane 4: 60 min; and lane 5: 90 min. (C,D) Optimization of temperature, (C) Assessment was based on 1.5\% agarose gel electrophoresis and (D) HNB visualization of colour change. Lane $1: 63^{\circ} \mathrm{C}$; lane $2: 61^{\circ} \mathrm{C}$; lane $3: 59^{\circ} \mathrm{C}$; and lane $4: 57^{\circ} \mathrm{C}$. M indicates a 100 bp DNA marker. 
A

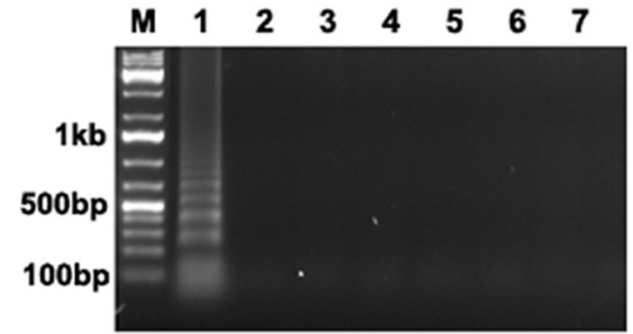

B

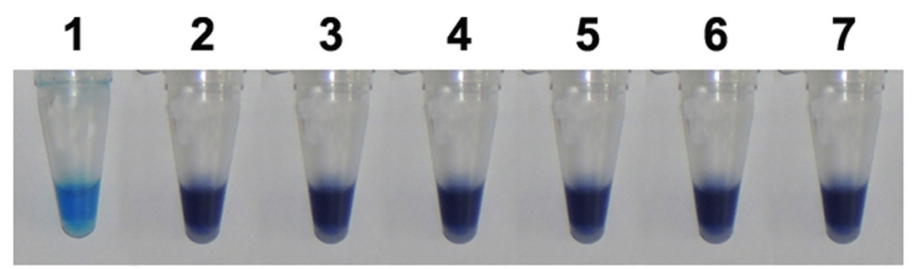

Figure 3 Specificity of the LAMP assay for Fusarium oxysporum f. sp. ciceris detection. (A) Detection of Fusarium oxysporum by LAMP assay on the basis of 1.5\% agarose gel electrophoresis. M indicates $100 \mathrm{bp}$ DNA marker. (B) Visual inspection of LAMP reaction tubes. Positive reactions turned sky blue after the addition of HNB. 1: Fusarium oxysporum f. sp. ciceris, 2: Fusarium acuminatum, 3: Fusarium udum, 4: Fusarium solani, 5: Rhizoctonia bataticola, 6: Alternaria alternata and 7: Phytophthora cajani.

\section{Sensitivity of the LAMP assay}

The sensitivity of the LAMP assay was assessed using serial dilutions of the fungal DNA as template under optimized condition. Figure 4A shows that the LAMP products consisted of ladder like DNA fragments were amplified upto $10 \mathrm{fg}$, giving a sensitivity of about $100 \mathrm{pg}$ of the fungal DNA. Although the amplified DNA fragments were slightly faint in $10 \mathrm{fg}$ sample than those produced by a greater amount of DNA. In contrast, when same amount of DNA was used in conventional PCR no such amplification was obtained at higher dilutions (Figure 4B). Similar result was obtained when detection was carried out by involving HNB dye also (Figure 4C). It indicated the detection limit of genomic DNA for LAMP assay was $10 \mathrm{fg}$ and $100 \mathrm{pg}$ for conventional PCR. These results also indicated that visual detection can be correlated with the results from agarose gel electrophoresis.

\section{Discussion}

To the best of our knowledge, this is the first report on the application of the LAMP assay for detection of Foc. Relative to conventional PCR, the LAMP assay reported here is easier to perform and more rapid, and the results are easier to evaluate. LAMP operates under isothermal conditions; the optimal temperature for detection of Foc was determined to be $63^{\circ} \mathrm{C}$ in this study. LAMP is also rapid; for detection of Foc, 60 min was determined to be optimum. Because LAMP is conducted at one temperature, no time is mislaid as a result of changes in temperature, as is the case with thermal cycling with PCR. Moreover, LAMP requires only a regular laboratory bath or heat block that can provide a constant temperature of $63^{\circ} \mathrm{C}$. Another very important advantage of LAMP is that the amplified products can be visually detected by adding the dye hydroxynaphthol blue (HNB), i.e., electrophoresis is not required. Because the LAMP assay is simple, it should be useful even for those laboratories and research institutes that are unfamiliar with PCR or other methods of molecular analysis. The simplest way of detecting LAMP products is to inspect the white turbidity that results from magnesium pyrophosphate accumulation, as a by-product of the reaction, by naked eye [26].

However, a small amount of this white precipitate is not always distinguishable from other white precipitates, such as proteins or carbohydrates, derived from the templates. As an alternative method, this study employed metal-ion indicators such as hydroxynaphthol blue (HNB) for low-cost detection of amplified DNA. The results obtained by this system were consistent with those obtained by gel electrophoresis. Since the detection can be accomplished in a closed system without opening the reaction tubes, the risk of contamination is much lower than in gel electrophoresis or by adding dye at the end of the reaction. Theoretically, it should be possible to replace hydroxynaphthol blue (HNB) with other dyes such as SYBR Green I [27-29], Ethidium bromide, EvaGreen [30], and PicoGreen [31] which are reported to be useful for the detection of LAMP products.

The LAMP assay developed here for detection of Foc using six primers: F3, B3, FIP, BIP, LF and LB. To confirm the efficiency and specificity of the six primers, we 


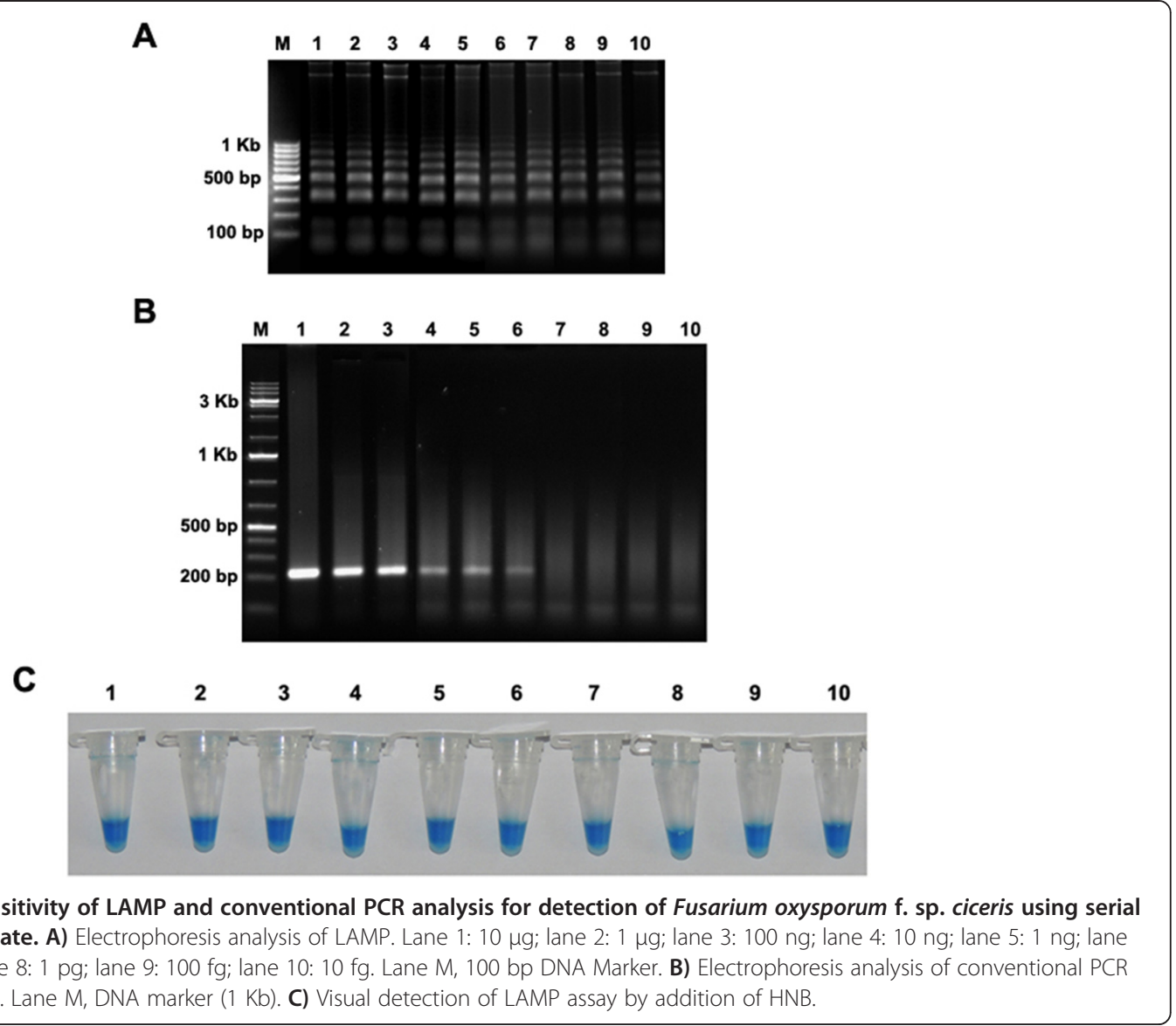

used DNA extracted from 50 isolates of Foc and from six other plant-pathogenic fungi as templates for LAMP assay. The LAMP assay correctly distinguished between Foc and other pathogens, as experimentation showed its inability to produce an amplification product from other pathogenic genome, thus confirming the LAMP assay and the primers designed here are specific for Foc.

As the LAMP reaction progresses, pyrophosphate ions are produced; these bind to $\mathrm{Mg}^{2+}$ ions and form a white precipitate of magnesium pyrophosphate. Therefore, the results of the LAMP can be judged by the unaided eye. This characteristic feature of the LAMP reaction means that the reaction end point can be detected simply by gauging the presence of a precipitate.

The addition of HNB before the LAMP reaction facilitates the determination of a positive result. HNB is a colorimetric indicator of calcium and alkaline earth metal ions. In a LAMP reaction mixture, dNTPs can influence the colour of HNB by the chelating with the $\mathrm{Mg}^{2+}$ ions. In the presence of $\mathrm{HNB}$, the colour gradually changes from violet to sky blue as the dNTPs decrease during amplification [20]. In this study, $150 \mu \mathrm{M} \mathrm{HNB}$ successfully distinguished between positive and negative samples. Compared to other methods used to visually detect endpoints, such as those based on the visualization of turbidity [32], the addition of DNA intercalating dyes [33-35], or the use of calcein [17], the use of HNB is simpler [36]. HNB can be added before incubation so that amplification is completed in a closed tube system, and detection of the colour change requires no equipment. The positive and negative reactions obtained with LAMP and HNB were confirmed when the LAMP products were subjected to gel electrophoresis analysis in the current study.

LAMP reaction might be facilitated by the addition of loop-forward and loop backward primers [19]. In the present study, we have identified suitable loop-forward primer and backward primer, and so we used loopforward primer and backward primer to accelerate the reaction (Table 1). This improved the reaction time and efficiency.

To test the LAMP utility, 50 isolates of all Foc were subjected to LAMP and conventional PCR. Compared with the other methods, the newly developed LAMP assay significantly improved the detection efficiency. Therefore, the LAMP assay can be used for detection of Foc in plants. 
Table 1 Information on the primers used in this study

\begin{tabular}{lll}
\hline Primer name & Sequence $\mathbf{( 5}^{\prime}$ - $\mathbf{3}^{\prime}$ ) & Length $\mathbf{( b p )}$ \\
\hline F3 & ACAACCTCAATGAGTGCG & 18 \\
B3 & CATGAGCGACAACATACCA & 19 \\
FIP (F1C + F2) & CCAGGCGTACTTGAAGGAACC & 41 \\
& GTCAAGCAGTCACTAACCAT & \\
BIP (B1C+ B2) & AGCGTGAGCGTGGTATCAC & 37 \\
& ACGGTGACATAGTAGCGA & \\
LoopF & GCTCAGCGGCTTCCTATT & 18 \\
LoopB & CTCTGGAAGTCGAGCATCC & 20 \\
ITS-1 & TCCGTAGGTGAACCTGCGG & 19 \\
ITS-4 & TCCTCCGCTTATTGATATGC & 20 \\
\hline
\end{tabular}

\section{Conclusion}

In conclusion, it was found that a LAMP assay combined with HNB is simple, rapid, sensitive and specific. Because this LAMP assay does not require specialized equipment, it can be used in the field for the rapid detection of Foc. This is the first report of the use of LAMP assay for the detection of Foc. It is a promising assay for extensive application and rapid diagnosis of Foc infection in the laboratory and will be very useful for monitoring the disease complex in the field further suggesting management strategies.

\section{Methods}

\section{Fungal culture}

A total of 50 Foc isolates collected from 21 locations representing 12 states and five agro-ecological zones of India (Central zone, North east plain zone, North hill zone, North west plain zone and South zone) were used in the present study to validate the LAMP assay (Table 2). All the isolates were purified and monoconidial cultures were maintained on potato dextrose agar (PDA) slants at $4^{\circ} \mathrm{C}$. The pathogenicity of all the isolates was proved following root-dip inoculation method under controlled environmental conditions [37]. Other Plant Pathogens used in this study are maintained in a collection in the Legumes Pathology Division, ICRISAT, India.

\section{DNA extraction}

Fungal DNA extraction was done by following cetyltrimethylammonium bromide (CTAB) method [38]. All the 50 isolates were grown in PDB and incubated in a rotary shaker at $120 \mathrm{rpm}$ at $25 \pm 1^{\circ} \mathrm{C}$ for five days. In brief, mycelia were harvested by filtering through mira cloth, and washed repeatedly with sterile distilled water to remove excess of salts adhering to it. One gram mycelium was crushed in liquid nitrogen and transferred into $7.5 \mathrm{ml}$ pre-warmed $\left(65^{\circ} \mathrm{C}\right)$ DNA extraction buffer $[1 \mathrm{M}$ Tris$\mathrm{HCl}(\mathrm{pH} 8.0), 5 \mathrm{M} \mathrm{NaCl}, 0.5 \mathrm{M}$ ethylene diamine tetra acetic acid (EDTA; pH 8.0) and 2\% CTAB], mixed well and incubated in a water bath at $65^{\circ} \mathrm{C}$ with gentle shaking for $45 \mathrm{~min}$. Equal volume of chloroform: isoamyl alcohol $(24: 1 \mathrm{v} / \mathrm{v})$ was added and mixed gently to denature proteins and centrifuged at $12,857 \mathrm{~g}$ for $10 \mathrm{~min}$. DNA was precipitated with 0.6 volume of chilled ethanol and 0.1 volume of $3 \mathrm{M}$ sodium acetate $(\mathrm{pH} 5.2)$ and centrifuged at 18,514 $\mathrm{g}$ for $15 \mathrm{~min}$. The pellets were washed twice with chilled $70 \%$ ethanol, dried at room temperature, re suspended in $100 \mu \mathrm{l}$ sterile TE $(10 \mathrm{mM}$ Tris- $\mathrm{HCl}$ buffer and $1 \mathrm{mM}$ EDTA; $\mathrm{pH} 8$ ) and stored at $-20^{\circ} \mathrm{C}$. Isolated DNA was run in $0.8 \%$ agarose gels and spectrophotometric analysis (Nanodrop spectrophotometer, Thermo Scientific, USA) to check the quality and quantity of DNA. Similarly, genomic DNA from the infected plants from chickpea fields was extracted using PureLink plant total DNA purification kit (Invitrogen, USA) following manufacturer's instructions. Quality and quantity of DNA was evaluated on $0.8 \%$ agarose gel as well as by spectrophotometric analysis and stored at $-20^{\circ} \mathrm{C}$ for further use.

\section{Primer design}

Six specific LAMP primers were designed based on the Foc elongation factor 1 alpha (EF-1alpha) gene (FJ538243). Specific primers based on the EF-1alpha gene sequence alignment were designed for LAMP detection of Foc using the LAMP designer software program (http:// lamp-designer.software.informer.com/). The structure of the LAMP primers and their complementarity to target DNA used in this study are shown in Figure 5. A forward inner primer (FIP) consisted of the complementary sequence of F1 (F1C) and F2, and a backward inner primer (BIP) consisted of B1C and B2. The outer primers $\mathrm{F} 3$ and $\mathrm{B} 3$ are required for initiation of the LAMP reaction. Primer pair ITS-1 and ITS-4 were used for conventional PCR. Information regarding the primer names and sequences is provided in Table 1.

\section{Optimization of LAMP reaction conditions}

The LAMP reaction mixtures (HNB and with or without Foc DNA as template) were incubated for $60 \mathrm{~min}$ from $57^{\circ} \mathrm{C}$ to $63^{\circ} \mathrm{C}$ to determine the optimal reaction temperature. Then, the LAMP was performed at the optimal reaction temperature for $15,30,45,60$, and $90 \mathrm{~min}$ to determine the optimal reaction time. The reactions were terminated by heat inactivation at $80^{\circ} \mathrm{C}$ for $10 \mathrm{~min}$. The assay was assessed based on HNBvisualized colour change and then on gel electrophoresis as described in the previous section.

\section{Evaluation of the LAMP assay}

Total 50 isolates of Foc collected from diverse geographical locations and representing Foc races in India were 
Table 2 Passport information of isolates used in Fusarium oxysporum f. sp. ciceris LAMP assay development and their LAMP reaction

\begin{tabular}{|c|c|c|c|c|c|c|c|c|}
\hline S. no & Isolate ID & Location & State & Agro-ecological zone* & Latitude & Longitude & Elevation (m) & LAMP reaction \\
\hline 1 & Foc_1 & Patancheru & Andhra Pradesh & $S Z$ & $17^{\circ} 31^{\prime} 53^{\prime \prime} \mathrm{N}$ & $78^{\circ} 15^{\prime} 54^{\prime \prime} \mathrm{E}$ & 516 & + \\
\hline 2 & Foc_2 & Patancheru & Andhra Pradesh & $\mathrm{SZ}$ & $17^{\circ} 31^{\prime} 53^{\prime \prime} \mathrm{N}$ & $78^{\circ} 15^{\prime} 54^{\prime \prime} \mathrm{E}$ & 516 & + \\
\hline 3 & Foc_3 & Patancheru & Andhra Pradesh & $\mathrm{SZ}$ & $17^{\circ} 31^{\prime} 53^{\prime \prime} \mathrm{N}$ & $78^{\circ} 15^{\prime} 54^{\prime \prime} \mathrm{E}$ & 516 & + \\
\hline 4 & Foc_4 & Patancheru & Andhra Pradesh & $S Z$ & $17^{\circ} 31^{\prime} 53^{\prime \prime} \mathrm{N}$ & $78^{\circ} 15^{\prime} 54^{\prime \prime} \mathrm{E}$ & 516 & + \\
\hline 5 & Foc_5 & Patancheru & Andhra Pradesh & $S Z$ & $17^{\circ} 31^{\prime} 53^{\prime \prime} \mathrm{N}$ & $78^{\circ} 15^{\prime} 54^{\prime \prime} \mathrm{E}$ & 516 & + \\
\hline 6 & Foc_6 & Patancheru & Andhra Pradesh & $S Z$ & $17^{\circ} 31^{\prime} 53^{\prime \prime} \mathrm{N}$ & $78^{\circ} 15^{\prime} 54^{\prime \prime} \mathrm{E}$ & 516 & + \\
\hline 7 & Foc_7 & Hisar & Haryana & NW PZ & $29^{\circ} 10^{\prime} 00^{\prime \prime} \mathrm{N}$ & $75^{\circ} 43^{\prime} 00^{\prime \prime} \mathrm{E}$ & 202 & + \\
\hline 8 & Foc_8 & Hisar & Haryana & NWPZ & $29^{\circ} 10^{\prime} 00^{\prime \prime} \mathrm{N}$ & $75^{\circ} 43^{\prime} 00^{\prime \prime} \mathrm{E}$ & 202 & + \\
\hline 9 & Foc_9 & Hisar & Haryana & NWPZ & $29^{\circ} 10^{\prime} 00^{\prime \prime} \mathrm{N}$ & $75^{\circ} 43^{\prime} 00^{\prime \prime} \mathrm{E}$ & 202 & + \\
\hline 10 & Foc_11 & Dhaulakuan & Himachal Pradesh & $\mathrm{NHZ}$ & $30^{\circ} 28^{\prime} 00^{\prime \prime} \mathrm{N}$ & $77^{\circ} 05^{\prime} 00^{\prime \prime} \mathrm{E}$ & 468 & + \\
\hline 11 & Foc_12 & Gulbarga & Karnataka & $S Z$ & $17^{\circ} 19^{\prime} 59^{\prime \prime} \mathrm{N}$ & $76^{\circ} 49^{\prime} 59^{\prime \prime} \mathrm{E}$ & 458 & + \\
\hline 12 & Foc_13 & Junagadh & Gujarat & $\mathrm{CZ}$ & $21^{\circ} 31^{\prime} 00^{\prime \prime} \mathrm{N}$ & $70^{\circ} 28^{\prime} 00^{\prime \prime} \mathrm{E}$ & 119 & + \\
\hline 13 & Foc_14 & Junagadh & Gujarat & $C Z$ & $21^{\circ} 31^{\prime} 00^{\prime \prime} \mathrm{N}$ & $70^{\circ} 28^{\prime} 00^{\prime \prime} \mathrm{E}$ & 119 & + \\
\hline 14 & Foc_16 & Badnapur & Maharashtra & $C Z$ & $19^{\circ} 52^{\prime} 00^{\prime \prime} \mathrm{N}$ & $75^{\circ} 43^{\prime} 60^{\prime \prime} \mathrm{E}$ & 498 & + \\
\hline 15 & Foc_17 & Badnapur & Maharashtra & $C Z$ & $19^{\circ} 52^{\prime} 00^{\prime \prime} \mathrm{N}$ & $75^{\circ} 43^{\prime} 60^{\prime \prime} \mathrm{E}$ & 498 & + \\
\hline 16 & Foc_20 & Delhi & Delhi & NWPZ & $28^{\circ} 40^{\prime} 00^{\prime \prime} \mathrm{N}$ & $77^{\circ} 13^{\prime} 00^{\prime \prime} \mathrm{E}$ & 213 & + \\
\hline 17 & Foc_21 & Ludhiana & Punjab & NWPZ & $30^{\circ} 54^{\prime} 00^{\prime \prime} \mathrm{N}$ & $75^{\circ} 51^{\prime} 00^{\prime \prime} \mathrm{E}$ & 243 & + \\
\hline 18 & Foc_22 & Ludhiana & Punjab & NWPZ & $30^{\circ} 54^{\prime} 00^{\prime \prime} \mathrm{N}$ & $75^{\circ} 51^{\prime} 00^{\prime \prime} \mathrm{E}$ & 243 & + \\
\hline 19 & Foc_23 & Gurdaspur & Punjab & NWPZ & $32^{\circ} 03^{\prime} 00^{\prime \prime} \mathrm{N}$ & $75^{\circ} 27^{\prime} 00^{\prime \prime} \mathrm{E}$ & 241 & + \\
\hline 20 & Foc_25 & Kanpur & Uttar Pradesh & NEPZ & $26^{\circ} 28^{\prime} 00^{\prime \prime} \mathrm{N}$ & $80^{\circ} 21^{\prime} 00^{\prime \prime} \mathrm{E}$ & 128 & + \\
\hline 21 & Foc_26 & Kanpur & Uttar Pradesh & NEPZ & $26^{\circ} 28^{\prime} 00^{\prime \prime} \mathrm{N}$ & $80^{\circ} 21^{\prime} 00^{\prime \prime} \mathrm{E}$ & 128 & + \\
\hline 22 & Foc_28 & Pantnagar & Uttarakhand & NWPZ & $29^{\circ} 20^{\prime} 04^{\prime \prime} \mathrm{N}$ & $79^{\circ} 28^{\prime} 25^{\prime \prime} \mathrm{E}$ & 344 & + \\
\hline 23 & Foc_29 & Kurnool & Andhra Pradesh & $S Z$ & $15^{\circ} 48^{\prime} 00^{\prime \prime} \mathrm{N}$ & $78^{\circ} 04^{\prime} 00^{\prime \prime} \mathrm{E}$ & 289 & + \\
\hline 24 & Foc_31 & Akola & Maharashtra & $C Z$ & $20^{\circ} 43^{\prime} 59^{\prime \prime} \mathrm{N}$ & $77^{\circ} 00^{\prime} 00^{\prime \prime} \mathrm{E}$ & 283 & + \\
\hline 25 & Foc_33 & Jabalpur & Madhya Pradesh & $C Z$ & $23^{\circ} 10^{\prime} 01^{\prime \prime} \mathrm{N}$ & $79^{\circ} 57^{\prime} 00^{\prime \prime} \mathrm{E}$ & 403 & + \\
\hline 26 & Foc_34 & Jabalpur & Madhya Pradesh & $C Z$ & $23^{\circ} 10^{\prime} 01^{\prime \prime} \mathrm{N}$ & $79^{\circ} 57^{\prime} 00^{\prime \prime} \mathrm{E}$ & 403 & + \\
\hline 27 & Foc_36 & Patancheru & Andhra Pradesh & $S Z$ & $17^{\circ} 31^{\prime} 53^{\prime \prime} \mathrm{N}$ & $78^{\circ} 15^{\prime} 54^{\prime \prime} \mathrm{E}$ & 516 & + \\
\hline 28 & Foc_37 & Dharwad & Karnataka & $S Z$ & $15^{\circ} 28^{\prime} 00^{\prime \prime} \mathrm{N}$ & $75^{\circ} 01^{\prime} 00^{\prime \prime} \mathrm{E}$ & 700 & + \\
\hline 29 & Foc_38 & Patancheru & Andhra Pradesh & $S Z$ & $17^{\circ} 31^{\prime} 53^{\prime \prime} \mathrm{N}$ & $78^{\circ} 15^{\prime} 54^{\prime \prime} \mathrm{E}$ & 516 & + \\
\hline 30 & Foc_39 & Kanpur & Uttar Pradesh & NEPZ & $26^{\circ} 28^{\prime} 00^{\prime \prime} \mathrm{N}$ & $80^{\circ} 21^{\prime} 00^{\prime \prime} \mathrm{E}$ & 128 & + \\
\hline 31 & Foc_45 & Delhi & Delhi & NWPZ & $28^{\circ} 40^{\prime} 00^{\prime \prime} \mathrm{N}$ & $77^{\circ} 13^{\prime} 00^{\prime \prime} \mathrm{E}$ & 213 & + \\
\hline 32 & Foc_47 & Dharwad & Karnataka & $S Z$ & $15^{\circ} 28^{\prime} 00^{\prime \prime} \mathrm{N}$ & $75^{\circ} 01^{\prime} 00^{\prime \prime} \mathrm{E}$ & 700 & + \\
\hline 33 & Foc_51 & Dhaulakuan & Himachal Pradesh & $\mathrm{NHZ}$ & $30^{\circ} 28^{\prime} 00^{\prime \prime} \mathrm{N}$ & $77^{\circ} 05^{\prime} 00^{\prime \prime} \mathrm{E}$ & 468 & + \\
\hline 34 & Foc_65 & Patancheru & Andhra Pradesh & SZ & $17^{\circ} 31^{\prime} 53^{\prime \prime} \mathrm{N}$ & $78^{\circ} 15^{\prime} 54^{\prime \prime} \mathrm{E}$ & 516 & + \\
\hline 35 & Foc_76 & Satna & Madhya Pradesh & $C Z$ & $24^{\circ} 34^{\prime} 59^{\prime \prime} \mathrm{N}$ & $80^{\circ} 49^{\prime} 59^{\prime \prime} \mathrm{E}$ & 318 & + \\
\hline 36 & Foc_79 & Rewa & Madhya Pradesh & $C Z$ & $24^{\circ} 31^{\prime} 59^{\prime \prime} \mathrm{N}$ & $81^{\circ} 18^{\prime} 00^{\prime \prime} \mathrm{E}$ & 275 & + \\
\hline 37 & Foc_87 & Rajnandgaon & Chhattisgarh & $C Z$ & $21^{\circ} 06^{\prime} 00^{\prime \prime} \mathrm{N}$ & $81^{\circ} 02^{\prime} 00^{\prime \prime} \mathrm{E}$ & 330 & + \\
\hline 38 & Foc_92 & Sehore & Madhya Pradesh & $C Z$ & $23^{\circ} 12^{\prime} 00^{\prime \prime} N$ & $77^{\circ} 04^{\prime} 59^{\prime \prime} \mathrm{E}$ & 502 & + \\
\hline 39 & Foc_93 & Patancheru & Andhra Pradesh & SZ & $17^{\circ} 31^{\prime} 53^{\prime \prime} \mathrm{N}$ & $78^{\circ} 15^{\prime} 54^{\prime \prime} \mathrm{E}$ & 516 & + \\
\hline 40 & Foc_95 & Kanpur & Uttar Pradesh & NEPZ & $26^{\circ} 28^{\prime} 00^{\prime \prime} \mathrm{N}$ & $80^{\circ} 21^{\prime} 00^{\prime \prime} \mathrm{E}$ & 128 & + \\
\hline 41 & Foc_96 & Kanpur & Uttar Pradesh & NEPZ & $26^{\circ} 28^{\prime} 00^{\prime \prime} \mathrm{N}$ & $80^{\circ} 21^{\prime} 00^{\prime \prime} \mathrm{E}$ & 128 & + \\
\hline 42 & Foc_100 & Jabalpur & Madhya Pradesh & $\mathrm{CZ}$ & $23^{\circ} 10^{\prime} 01^{\prime \prime} \mathrm{N}$ & $79^{\circ} 57^{\prime} 00^{\prime \prime} \mathrm{E}$ & 403 & + \\
\hline 43 & Foc_101 & Jabalpur & Madhya Pradesh & $C Z$ & $23^{\circ} 10^{\prime} 01^{\prime \prime} \mathrm{N}$ & $79^{\circ} 57^{\prime} 00^{\prime \prime} \mathrm{E}$ & 403 & + \\
\hline
\end{tabular}


Table 2 Passport information of isolates used in Fusarium oxysporum f. sp. ciceris LAMP assay development and their LAMP reaction (Continued)

\begin{tabular}{|c|c|c|c|c|c|c|c|c|}
\hline 44 & Foc_115 & Satana & Madhya Pradesh & $C Z$ & $24^{\circ} 34^{\prime} 59^{\prime \prime} \mathrm{N}$ & $80^{\circ} 49^{\prime} 59^{\prime \prime} \mathrm{E}$ & 318 & + \\
\hline 45 & Foc_116 & Satana & Madhya Pradesh & $C Z$ & $24^{\circ} 34^{\prime} 59^{\prime \prime} \mathrm{N}$ & $80^{\circ} 49^{\prime} 59^{\prime \prime} \mathrm{E}$ & 318 & + \\
\hline 46 & Foc_118 & Satana & Madhya Pradesh & $C Z$ & $24^{\circ} 34^{\prime} 59^{\prime \prime} \mathrm{N}$ & $80^{\circ} 49^{\prime} 59^{\prime \prime} \mathrm{E}$ & 318 & + \\
\hline 47 & Foc_119 & Damoh & Madhya Pradesh & $C Z$ & $23^{\circ} 49^{\prime} 59^{\prime \prime} \mathrm{N}$ & $79^{\circ} 27^{\prime} 00^{\prime \prime} \mathrm{E}$ & 354 & + \\
\hline 48 & Foc_131 & Rewa & Madhya Pradesh & $C Z$ & $24^{\circ} 31^{\prime} 59^{\prime \prime} \mathrm{N}$ & $81^{\circ} 18^{\prime} 00^{\prime \prime} \mathrm{E}$ & 275 & + \\
\hline 49 & Foc_132 & Satana & Madhya Pradesh & $C Z$ & $24^{\circ} 34^{\prime} 59^{\prime \prime} \mathrm{N}$ & $80^{\circ} 49^{\prime} 59^{\prime \prime} \mathrm{E}$ & 318 & + \\
\hline 50 & Foc_145 & Katni & Madhya Pradesh & $C Z$ & $23^{\circ} 47^{\prime} 00^{\prime \prime} \mathrm{N}$ & $80^{\circ} 27^{\prime} 00^{\prime \prime} \mathrm{E}$ & 392 & + \\
\hline
\end{tabular}

${ }^{*} \mathrm{CZ}$ - Central zone, NEPZ - North east plain zone, NHZ - North hill zone, NWPZ - North west plain zone and SZ - South zone.

subjected to LAMP and conventional PCR. When LAMP reactions were finished, they were assessed on colour change and based on gel electrophoresis as described earlier.

\section{Specificity of the LAMP}

LAMP specificity was determined by performing the assay with fungal DNA from Foc and six other plantpathogenic fungi (Fusarium acuminatum, Fusarium udum, Fusarium solani, Rhizoctonia bataticola, Alternaria alternata and Phytophthora cajani). Similarly LAMP assay was performed with DNA isolated from infected field samples of chickpea (Black root rot caused by Fusarium solani, Dry root rot caused by Rhizoctonia bataticola and Alternaria blight caused by Alternaria alternata) as described earlier at $63^{\circ} \mathrm{C}$ for $60 \mathrm{~min}$. The assay was assessed based on HNB-visualized colour change and then by gel electrophoresis. Each fungal sample was represented by three replications, and the experiment was performed three times.

\section{LAMP sensitivity}

LAMP sensitivity assay was detected by comparing the assay with conventional PCR method by using different concentrations of DNA sample. The LAMP assay was performed by using a serially diluted DNA samples at concentrations range from $10 \mu \mathrm{g}$ to $10 \mathrm{fg}$. The purified DNA was dissolved in double-distilled water, and $1 \mu \mathrm{l}$ of the solution was used as the template for LAMP. For the conventional PCR run the DNA was amplified with ITS-1 and ITS-4 primers with similar concentrations of DNA. Template DNA from Foc was prepared as described earlier and was serially diluted from $10 \mu \mathrm{g}$ to $10 \mathrm{fg}$. The samples were then subjected to LAMP (with HNB) and PCR assays. After completion of the reaction both the reactions were assessed; the LAMP products

\section{ATC GAC AAG CGAACC ATC GAG AAG TTC GAG AAG GTT AGT CAC TTT CCC TTC \\ 256 GAT CGC GCG TCC TTT GCC CAT CGA TTT CCC CTA CGA CTC GAA ACG TGC CCG \\ 307 CTA CCC CGC TCG AGA CCA AAA ATT TTG CAA TAT GAC CGT AAT TTT TTT GGT \\ 358 GGG GCA CTT ACC CCG CCA CTT GAG CGA CGG GAG CGT TTG CCC TCT TAC CAT \\ 409 TCA CAA CCT CAA TGA GTG CGT COT CAC GT $\stackrel{\text { GCAAGC AGT CAC TAA CCA T }}{\longrightarrow}$ \\ 460 AAC AAT AGG AAG CCG CTGAGC TCG GTAAGG GTT CCT TCAAGT ACG CCT GGG \\ $\mathrm{BlC} \longrightarrow$ \\ 511 TTC TTG ACA AGC TCAAGG CCG AGC GTG AGC GTG GTA TCA CCA TCG ATA TTG \\ 562 CTCTCT GGAAGT TCG AGACTC dTC GCT ACT ATG TCACCG TCA TTG GTATGT

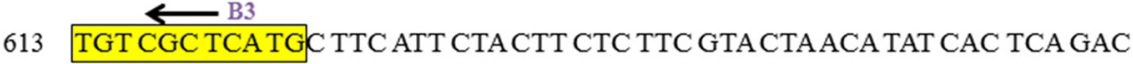 \\ 664 GCT CCC GGT CAC CGT GAT TTC ATC AAG AAC ATG ATC ACT GGT ACT TCC A}

Figure 5 Schematic representation of Position and sequence of primer sets within the nucleotide sequence of the elongation factor 1 alpha gene of Fusarium oxysporum f. sp. ciceris used for LAMP assay. Arrows and box indicate the position of the target sequences. 
were visualized as described earlier, while the PCR products were observed by gel electrophoresis.

\section{Additional file}

Additional file 1: Figure S1: Specificity of LAMP assay with DNA isolated from infected chickpea plant. Tube 1: DNA isolated from infected sample of Fusarium wilt showing positive result. Tube 2: DNA isolated from infected sample of Black root rot. Tube 3: DNA isolated from infected sample of Dry root rot, Tube 4: DNA isolated from infected sample of Alternaria blight. Assessment based on HNB visualization of colour change.

\section{Abbreviations}

EF-1alpha: Elongation factor 1 alpha; Foc: Fusarium oxysporum f. sp. ciceris; HNB: Hydroxynaphthol blue; ITS: Internal transcribed spacer; LAMP: Loopmediated isothermal amplification.

\section{Competing interests}

The authors declare that they have no competing interests.

\section{Authors' contributions}

MS and RG conceived the study and were responsible for designing the experiments, analysing and interpretation of results, and drafting the manuscript; NV conducted extraction of DNA and helped in LAMP assay development. AS helped in compiling the data and drafting the manuscript. All authors read and approved the manuscript.

\section{Acknowledgement}

The funding support from Department of Science and Technology-Climate Change Division, Govt. of India is gratefully acknowledged. The authors are thankful for technical assistance from Mr. Bala Krishna from Legumes

Pathology group in DNA isolation and culture maintenance.

Received: 6 November 2014 Accepted: 26 January 2015

\section{Published online: 11 February 2015}

\section{References}

1. FAOSTAT. Agriculture. http://faostat.fao.org.

2. AGRISTAT. Statistics at a glance 2011. http://agricoop.nic.in/agristatics.htm.

3. Haware MP, Nene YL. Races of Fusarium oxysporum. Plant Dis. 1982;66:809-10.

4. Halila MH, Strange RN. Identification of the causal agent of wilt of chickpea in Tunisia as Fusarium oxysporum f. sp. ciceri race. Phytopathol Mediterr. 1996;35:67-74

5. Navas-Cortes JA, Hau B, Jimeńez-Dláz RM. Yield loss in chickpeas in relation to development of Fusarium wilt epidemics. Phytopathology. 2000;90:1269-78.

6. Jimeńez-Gasco MM, Navas-Cortes JA, Jimeńez-Diaz RM. The Foc/Cicer a pathosystem: a case study of the evolution of plant-pathogenic fungi into races and pathotypes. Internat Microbiol. 2004;7:95-104.

7. Sharma M, Nagavardhini A, Thudi M, Ghosh R, Pande S, Varshney RK. Development of DArT markers and assessment of diversity in Fusarium oxysporum f. sp. ciceris, wilt pathogen of chickpea (Cicer arietinum L.). BMC Genomics. 2014;15:454.

8. Faburay B, Geysen D, Munstermann S, Bell-Sakyi L, Jongejan F. Longitudina monitoring of Ehrlichia ruminantium infection in Gambian lambs and kids by pCS20 PCR and MAP1-B ELISA. BMC Infect Dis. 2007;7:85.

9. Martinez D, Vachiéry N, Stachurski F, Kandassamy Y, Raliniaina M, Aprelon R, et al. Nested PCR for detection and genotyping of Ehrlichia ruminantium: use in genetic diversity analysis. Ann N Y Acad Sci. 2004;1026:106-13.

10. Peixoto CC, Marcelino I, Vachiéry N, Bensaid A, Martinez D, Carrondo MJ, et al. Quantification of Ehrlichia ruminantium by real time PCR. Vet Microbiol. 2005;107:273-8.

11. Steyn HC, Pretorius A, McCrindle CM, Steinmann CM, Van Kleef M. A quantitative real-time PCR assay for Ehrlichia ruminantium using pCS20. Vet Microbiol. 2008;131:258-65.

12. Pan L, Zhang L, Wang G, Liu Q, Yu Y, Wang S, et al. Rapid, simple, and sensitive detection of Anaplasma phagocytophilum by loop-mediated isothermal amplification of the msp2 Gene. Mol Biol Rep. 2011;38(6):4063-70.
13. Opel KL, Chung D, McCord BR. A study of PCR inhibition mechanisms using real time PCR. J Forensic Sci. 2010;55:25-33.

14. Notomi T, Okayama H, Masubuchi H, Yonekawa T, Watanabe K, et al. Loop-mediated isothermal amplification of DNA. Nucleic Acids Res. 2000;28:E63.

15. Mori Y, Notomi T, Loop-mediated isothermal amplification (LAMP). A rapid, accurate, and cost-effective diagnostic method for infectious diseases. $J$ Infect Chemother. 2009;15:62-9.

16. Caipang CM, Haraguchi I, Ohira T, Hirono I, Aoki T. Rapid detection of a fish iridovirus using loop-mediated isothermal amplification (LAMP). J Virol Methods. 2004;121:155-61.

17. Tomita N, Mori Y, Kanda H, Notomi T. Loop-mediated isothermal amplification (LAMP) of gene sequences and simple visual detection of products. Nat Protoc. 2008:3:877-82.

18. Kaneko H, Kawana T, Fukushima E, Suzutani T. Tolerance of loop-mediated isothermal amplification to a culture medium and biological substances. J Biochem Biophys Methods. 2007;70:499-501.

19. Nagamine K, Hase T, Notomi T. Accelerated reaction by loop-mediated isothermal amplification using loop primers. Mol Cell Probes. 2002;16:223-9.

20. Goto M, Honda E, Ogura A, Nomoto A, Hanaki K. Colorimetric detection of loop-mediated isothermal amplification reaction by using hydroxy naphthol blue. Biotechniques. 2009:46:167-72.

21. Zoheir KM, Allam AA. A rapid improved method for sexing embryo of water buffalo. Theriogenology. 2011;76:83-7.

22. Bekele B, Hodgetts J, Tomlinson J, Boonham N, Nikolić P, Swarbrick P, et al. Use of a real-time LAMP isothermal assay for detecting 165 Sill and 165 rXII phytoplasmas in fruit and weeds of the Ethiopian Rift Valley. Plant Pathol. 2011;60:345-55.

23. Pan $W$, Wang JY, Shen $H Y$, Zhao MQ, Ju CM, Dong XY, et al. Development and application of the novel visual loopmediated isothermal amplification of Omp25 sequence for rapid detection of Brucella sp. J Anim Vet Adv. 2011;10:2120-6.

24. Parida M, Posadas G, Inoue S, Hasebe F, Morita K. Realtime reverse transcription loop-mediated isothermal amplification for rapid detection of West Nile virus. J Clin Microbiol. 2004;42:257-63.

25. Niessen L, Vogel RF. Detection of Fusarium graminearum DNA using a loopmediated isothermal amplification (LAMP) assay. Int J Food Microbiol. 2010;140:183-91.

26. Mori Y, Nagamine K, Tomita N, Notomi T. Detection of loop-mediated isothermal amplification reaction by turbidity derived from magnesium pyrophosphate formation. Biochem Biophys Res Commun. 2001;289:150-4

27. Bista BR, Ishwad C, Wadowsky RM, Manna P, Randhawa PS, Gupta G, et al. Development of a loop-mediated isothermal amplification assay for rapid detection of BK virus. J Clin Microbiol. 2007:45:1581-7.

28. Iwamoto T, Sonobe T, Hayashi K. Loop-mediated isothermal amplification for direct detection of Mycobacterium tuberculosis complex, M. avium, and M. intracellulare in sputum samples. J Clin Microbiol. 2003;41:2616-22.

29. Yoshida A, Nagashima S, Ansai T, Tachibana M, Kato H, Watari H, et al. Loopmediated isothermal amplification method for rapid detection of the periodontopathic bacteria Porphyromonas gingivalis, Tannerella forsythia, and Treponema denticola. J Clin Microbiol. 2005;43:2418-24.

30. Qiao YM, Guo YC, Zhang XE, Zhou YF, Zhang ZP, Wei HP, et al. Loopmediated isothermal amplification for rapid detection of Bacillus anthracis spores. Biotechnol Lett. 2007;29:1939-46.

31. Tomlinson JA, Barker I, Boonham N. Faster, simpler, more-specific methods for improved molecular detection of Phytophthora ramorum in the field. Appl Environ Microbiol. 2007;73:4040-7.

32. Nowotny N, Mostl K, Maderbacher R, Odorfer G, Schuh M. Serological studies in Austrian fattening pigs with respiratory disorders. Acta Vet Hung 1994:42:377-9.

33. Curtis KA, Rudolph DL, Owen SM. Rapid detection of HIV-1 by reversetranscription, loop-mediated isothermal amplification (RT-LAMP). J Virol Methods. 2008;151:264-70.

34. Hill J, Beriwal S, Chandra I, Paul VK, Kapil A, et al. Loop-mediated isothermal amplification assay for rapid detection of common strains of Escherichia coli. J Clin Microbiol. 2008;46:2800-4.

35. Parida M, Horioke K, Ishida H, Dash PK, Saxena P, Jana AM, et al. Rapid detection and differentiation of dengue virus serotypes by a real-time reverse transcription-loop-mediated isothermal amplification assay. J Clin Microbiol. 2005;43:2895-903. 
36. Wastling SL, Picozzi K, Kakembo AS, Welburn SC. LAMP for human African trypanosomiasis: a comparative study of detection formats. PLOS Neglect Trop D. 2010;4:e865.

37. Pande S, Rao NJ, Sharma M. Establishment of chickpea wilt pathogen Fusarium oxysporum f. sp. ciceris in the soil through seed transmission. Plant Pathol J. 2007;23(1):3-6.

38. Murray MG, Thompson WF. Rapid isolation of high molecular weight DNA. Nucleic Acids Res. 1980;8:4321-5.

Submit your next manuscript to BioMed Central and take full advantage of:

- Convenient online submission

- Thorough peer review

- No space constraints or color figure charges

- Immediate publication on acceptance

- Inclusion in PubMed, CAS, Scopus and Google Scholar

- Research which is freely available for redistribution 